\title{
Researchon Concrete Box Girder (Single \& Double Cells) Bridges using Finite Element Method
}

\author{
D.V.S. KChaitanya
}

\begin{abstract}
Bridge construction today has achieved a worldwide level of importance. Extension development today has accomplished an overall dimension of significance. Extensions are the key components in any street system and utilization of strengthened support type spans picking up notoriety in scaffold building organization in light of its better security, functionality, economy, stylish appearance and auxiliary effectiveness. By and large for long range Box brace spans are progressively basic proficient. Box support opposes the torsional unbending nature and appropriate for critical bend.

For this investigation, four distinctive scaffold supports are viewed as specifically Rectangular Single and Double cell Box Girder (RSBG and RDBG), Trapezoidal Single and Double cell Box Girder (TSBG and TDBG) of ranges $20 \mathrm{~m}, 30 \mathrm{~m}, 40 \mathrm{~m}$ and $50 \mathrm{~m}$. Direct Static and Modal Analysis are performed on all the considered extension supports utilizing SAP2000 connect wizard. IRC Class AA Tracked Loading framework is considered for the examination. A near give an account of dynamic Characteristics of all the considered extension braces utilizing SAP2000.Keywords: Stiffness, modal analysis, Linear Static analysis, loading system, Dynamic Characteristics.
\end{abstract}

\section{INTRODUCTION:}

\section{GENERAL}

Bridges are defined as structures which can be provided a passage over a gap without ultimate manner beneath. They can be wanted for a passage of railway, roadway, footpath or even for carriage of fluid, bridge web site need to be so selected that it offers most industrial and social advantages, performance, effectiveness and equality. Bridges are state's lifelines and backbones in the event of war. Bridges represent ideals and aspirations of humanity. They span barriers that divide, carry people, groups and international locations into nearer proximity. Bridge production constitutes a significance element in communique and is an essential element in progress of civilization, bridges stand as tributes to the paintings of civil engineers.

\subsection{BOX GIRDER BRIDGE DECK}

A box girder bridge is a bridge in which the main beams comprise girders in the shape of a hollow box. The box girder normally comprises either prestressed concrete, structural steel, or a composite of steel and reinforced concrete. It is typically rectangular or trapezoidal in cross section. Box girder bridges are commonly used for highway flyovers and for modern elevated structures of light rail transport. The box girder can also be part of portal frame

Revised Manuscript Received on April 12, 2019.

D.V.S. KChaitanya, Department of Civil Engineering, A.N.U College of Engineering \&Technology, AcharyaNagarjuna University, Guntur, A.P, India. bridges, arch bridges, cable-stayed and suspension bridges of all kinds. Box girder decks are cast-in-place units that can be constructed to follow any desired alignment in plan, so that straight, skew and curved bridges of various shapes are common in the highway system. Because of high torsional resistance, a box girder structure is particularly suited to bridges with significant curvature.

SAP2000 can perform both linear static and multi-step static analysis. Certain types of load patternsare multistepped, meaning that they actually represent many separate spatial loading patterns applied in sequence. These include the vehicle, live, and wave types of load patterns. SAP2000.dynamic analysis capabilities include the calculation of vibration modes using Ritz or Eigen vectors, response-spectrum analysis, and time-history analysis for both linear and nonlinear behavior.

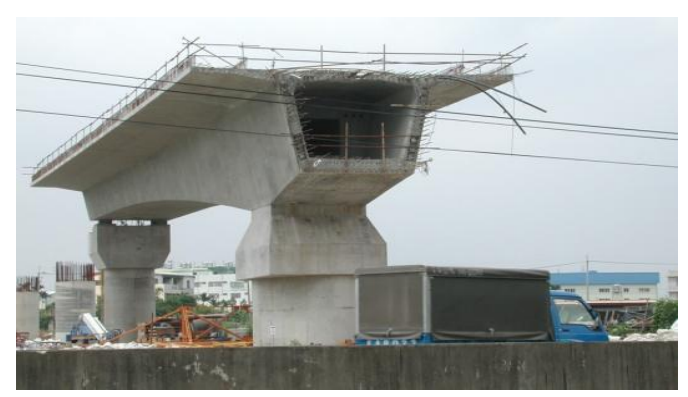

Figure 1.1 Box Girder Bride

\section{GEOMETRICAL CONFIGURATION OF THE BRIDGE DECKS}

\subsubsection{Rectangular Single cell Box Girder}

Table 2.1 Geometrical parameters of the Rectangular Single cell Box Girder (RSBG).

\begin{tabular}{|c|c|}
\hline Geometrical Parameter & Dimensions (m) \\
\hline Span of the Bridge Deck & 20 \\
\hline Total Width of the Deck & 8.7 \\
\hline $\begin{array}{c}\text { Carriage way Width of } \\
\text { the Deck }\end{array}$ & 7.5 \\
\hline Overall Depth of deck & 1.2 \\
\hline Width of the Beam & 0.3 \\
\hline $\begin{array}{c}\text { Thickness of the Deck } \\
\text { slab }\end{array}$ & 0.25 \\
\hline Cross girder width & 0.3 \\
\hline No. of cross girders & 5 \\
\hline
\end{tabular}

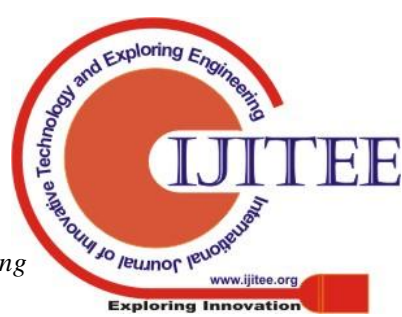




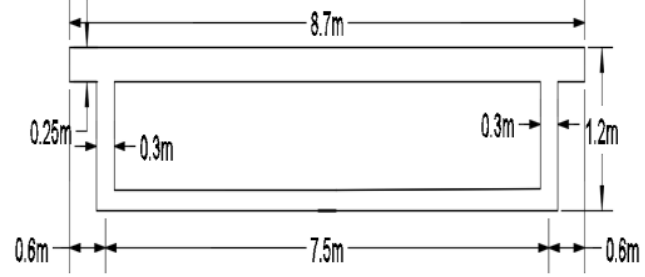

Figure 2.1 Cross section of Rectangular Single cell Box Girder.

Considered different span of the girder is $20 \mathrm{~m}, 30 \mathrm{~m}, 40 \mathrm{~m}$ and $50 \mathrm{~m}$ with a total depth of $1.2 \mathrm{~m}, 1.8 \mathrm{~m}, 2.4 \mathrm{~m}$ and $3.0 \mathrm{~m}$ respectively.

\subsubsection{Rectangular Double cell Box Girder}

Table 2.2 Geometrical parameters of the Rectangular Double cell Box Girder (RDBG)

\begin{tabular}{|c|c|}
\hline Geometrical Parameter & Dimension \\
\hline Span of the Bridge Deck & $20 \mathrm{~m}$ \\
\hline Total Width of the Deck & $8.7 \mathrm{~m}$ \\
\hline Width of the Deck & $7.5 \mathrm{~m}$ \\
\hline Depth of deck & $1.2 \mathrm{~m}$ \\
\hline Width of the beam & $0.3 \mathrm{~m}$ \\
\hline Thickness of the Deck slab & $0.25 \mathrm{~m}$ \\
\hline Thickness of the soffit slab & $0.25 \mathrm{~m}$ \\
\hline Cross girder & $0.3 \mathrm{~m}$ \\
\hline No. of cross girders & 5 \\
\hline
\end{tabular}

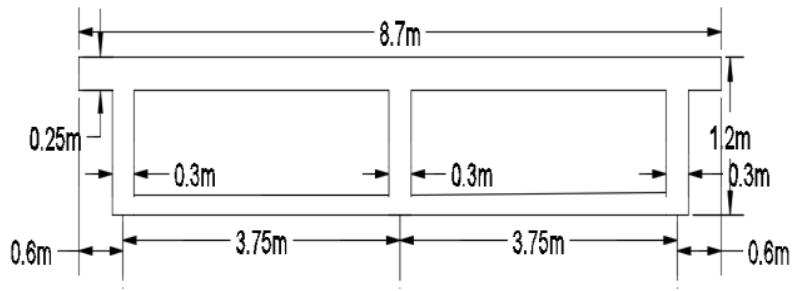

Figure 2.2 Cross section of Rectangular Double cell Box Girder.

Considered different span of the girder is $20 \mathrm{~m}, 30 \mathrm{~m}, 40 \mathrm{~m}$ and $50 \mathrm{~m}$ with a total depth of $1.2 \mathrm{~m}, 1.8 \mathrm{~m}, 2.4 \mathrm{~m}$ and $3.0 \mathrm{~m}$ respectively.

\subsubsection{Trapezoidal Single cell Box Girder}

Table 2.3. Geometrical parameters of the Trapezoidal Single Cell Box Girder (TSBG)

\begin{tabular}{|c|c|}
\hline Geometrical Parameter & Dimension \\
\hline Span of the Bridge Deck & $20 \mathrm{~m}$ \\
\hline Total Width of the Deck & $8.7 \mathrm{~m}$ \\
\hline Width of the Deck & $7.5 \mathrm{~m}$ \\
\hline Depth of deck & $1.2 \mathrm{~m}$ \\
\hline Width of the beam & $0.3 \mathrm{~m}$ \\
\hline Thickness of the Deck slab & $0.25 \mathrm{~m}$ \\
\hline Thickness of the soffit slab & $0.25 \mathrm{~m}$ \\
\hline Cross girder & $0.3 \mathrm{~m}$ \\
\hline No. of cross girders & 5 \\
\hline
\end{tabular}

Girder.

Considered different span of the girder is $20 \mathrm{~m}, 30 \mathrm{~m}, 40 \mathrm{~m}$ and $50 \mathrm{~m}$ with a total depth of $1.2 \mathrm{~m}, 1.8 \mathrm{~m}, 2.4 \mathrm{~m}$ and $3.0 \mathrm{~m}$ respectively.

\subsubsection{Trapezoidal Double cell Box Girder}

Table 2.4 Geometrical parameters of the Trapezoidal Double cell Box Girder (TDBG)

\begin{tabular}{|c|c|}
\hline Geometrical Parameter & Dimension \\
\hline Span of the Bridge Deck & $20 \mathrm{~m}$ \\
\hline Total Width of the Deck & $8.7 \mathrm{~m}$ \\
\hline Width of the Deck & $7.5 \mathrm{~m}$ \\
\hline Depth of deck & $1.2 \mathrm{~m}$ \\
\hline Width of the beam & $0.3 \mathrm{~m}$ \\
\hline Thickness of the Deck slab & $0.25 \mathrm{~m}$ \\
\hline Thickness of the soffit slab & $0.25 \mathrm{~m}$ \\
\hline Cross girder & $0.3 \mathrm{~m}$ \\
\hline No. of cross girders & 5 \\
\hline
\end{tabular}

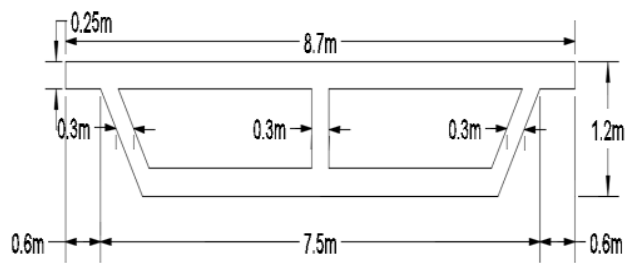

Figure 2.4 Cross section of Trapezoidal Double cell Box Girder.

Considered different span of the girder is $20 \mathrm{~m}, 30 \mathrm{~m}, 40 \mathrm{~m}$ and $50 \mathrm{~m}$ with a total depth of $1.2 \mathrm{~m}, 1.8 \mathrm{~m}, 2.4 \mathrm{~m}$ and $3.0 \mathrm{~m}$ respectively.

\subsection{MATERIAL PROPERTIES OF THE BRIDGE GIRDERS}

Table 3.5, shows the material properties of the bridge girders.

Table 2.5 Properties of the bridge girders.

\begin{tabular}{|c|c|c|}
\hline Concrete & Density & $25 \mathrm{kN} / \mathrm{m}^{3}$ \\
\hline \multirow{4}{*}{ Steel } & Poisson's Ratio & 0.2 \\
\cline { 2 - 3 } & Young's Modulus & $33.5 \mathrm{E}+06 \mathrm{kN} / \mathrm{m}^{2}$ \\
\cline { 2 - 3 } & Grade Of Concrete & $\mathrm{M} 25$ \\
\hline \multirow{5}{*}{} & Density & $78.5 \mathrm{kN} / \mathrm{m}^{3}$ \\
\cline { 2 - 3 } & Poisson's Ratio & 0.3 \\
\cline { 2 - 3 } & Young's Modulus & $200 \mathrm{E}+06 \mathrm{kN} / \mathrm{m}^{2}$ \\
\cline { 2 - 3 } & Yield Stress, $\mathrm{F}_{\mathrm{y}}$ & $0.6 \mathrm{GPa}$ \\
\hline
\end{tabular}




\subsection{LOADS CONSIDERED FOR THE STUDY}

Dead load and moving loads are considered based on IRC: 6-2010.

According to IRC: 6-2010, and other parameters we considered

- Dead Load (IRC 875 Part I)

- Moving Load (IRC 6 - 2010)

IRC Class AA Tracked Vehicle is considered for this study.

\section{RESULTS:}

\subsection{NATURAL TIME PERIOD AND FREQUENCIES}

Modal analysis is performed on different types of girders namely T-Bridge girder, Box Girder single cell, Box girder multi cell, box girder slope single cell and box girder slope multi cell and the resulting mode shapes are noted down for different spans. In the present analysis, only 3 modes are considered. Table 4.Shows the values of time period and frequencies for different girders and for different spans. As time period is inversely proportional to frequency, the Bridge with higher frequency values showed lower time period values

$$
\underset{\mathrm{T}}{\mathrm{f} \alpha \underline{1}}
$$

Table 3.1Natural Time Period and Frequencies for Different girders for $20 \mathrm{~m}$ Span

\begin{tabular}{|l|l|l|}
\hline GIRDERS & $\begin{array}{l}\text { Time } \\
\text { Period } \\
\text { (sec) }\end{array}$ & $\begin{array}{l}\text { Frequency } \\
\text { (cyc/sec) }\end{array}$ \\
\hline RSBG & 0.18 & 5.32 \\
\hline RDBG & 0.17 & 5.73 \\
\hline TSBG & 0.19 & 5.29 \\
\hline TDBG & 0.17 & 5.69 \\
\hline
\end{tabular}

\subsection{MODE SHAPES}

Modal analysis is performed on different spans and different types of bridge girders and mode shapes are shown below.

\subsection{For $20 m$ Span}

\subsection{1 (a) Rectangular Single cell Box Girder}

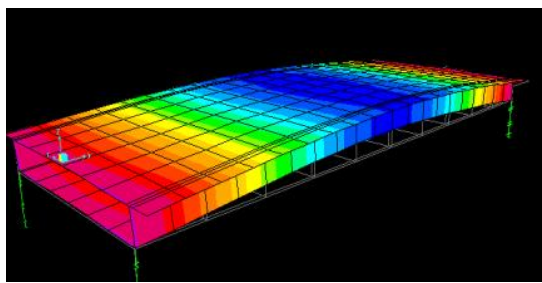

Figure 3.1 First Mode Shape for Rectangular Single cell Box Girder 20m Span.

\subsection{1 (b) Rectangular Double cell Box Girder}

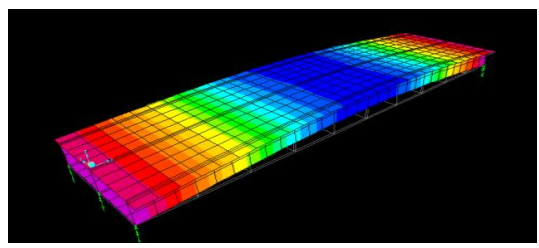

Figure 3.2 First Mode Shape for Rectangular Double cell Box Girder 20m Span.

\subsection{1 (c) Trapezoidal Single cell Box Girder}

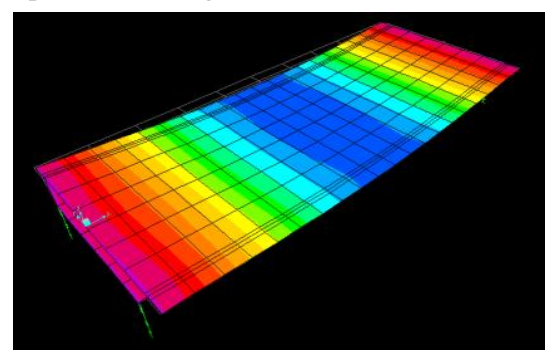

Figure 3.3 First Mode Shape for Trapezoidal Single cell Box Girder 20m Span.

3.3.1 (d) Trapezoidal Double cell Box Girder

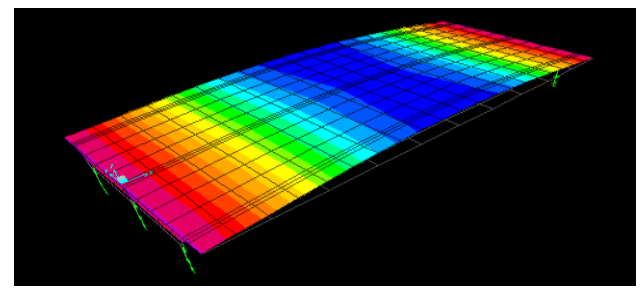

Figure 3.4 First Mode Shape for Trapezoidal Double cell Box Girder 20m Span.

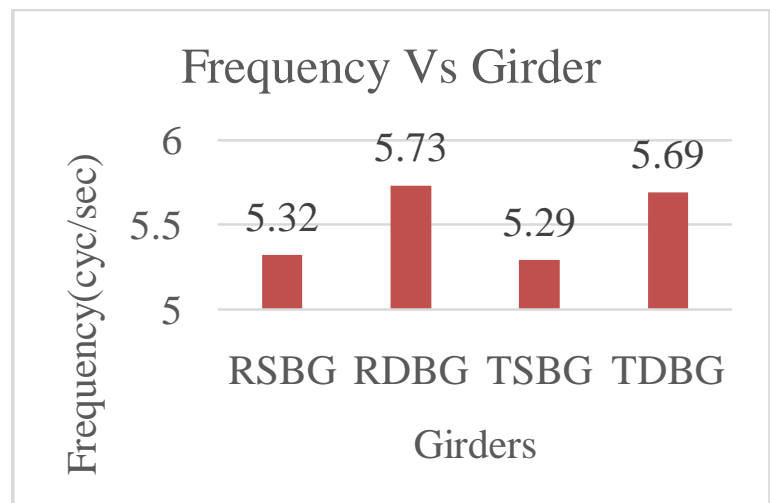

Figure 3.5 Frequency (cyc/sec) Values For different girders shapes for $20 \mathrm{~m}$ Span

From figure 3.5 , it is observed that the maximum frequency is for Rectangular Double cell Box Girder (RDBG) in all considered girders. It is observed that there is an increase in stiffness of $2 \%, 1 \%$ for RDBG and TDBG and decrease of $0.07 \%$ for TSBG when compared to RSBG.

Table 3.2 Natural Time Period and Frequencies for Different girders for 30m Span

\begin{tabular}{|l|l|l|}
\hline GIRDERS & $\begin{array}{l}\text { Time } \\
\text { Period } \\
\text { (sec) }\end{array}$ & $\begin{array}{l}\text { Frequency } \\
\text { (cyc/sec) }\end{array}$ \\
\hline RSBG & 0.23 & 4.23 \\
\hline RDBG & 0.22 & 4.51 \\
\hline TSBG & 0.22 & 4.15 \\
\hline TDBG & 0.21 & 4.61 \\
\hline
\end{tabular}

3.3.2 For 30m Span

3.3.2 (a) Rectangular Single cell Box Girder

Published By:

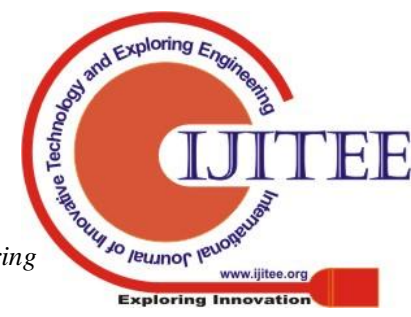




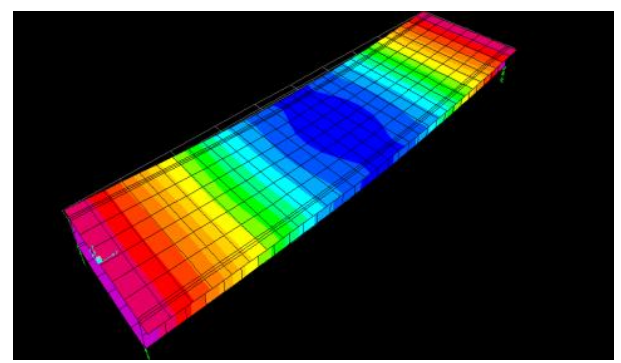

Figure 3.6 First Mode Shape for Rectangular Single cell Box Girder 30m Span.

\subsection{2 (b) Rectangular Double cell Box Girder}

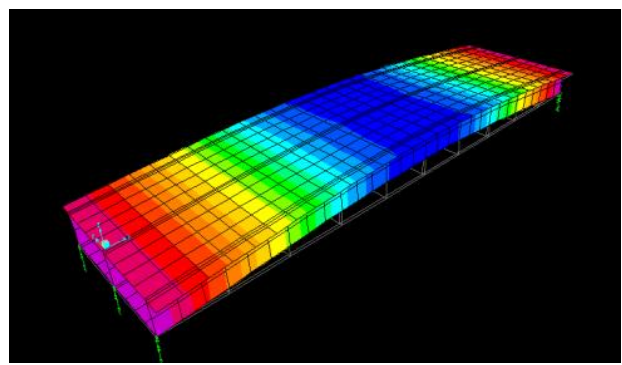

Figure 3.7 First Mode Shape for Rectangular Double cell Box Girder 30m Span.

\subsection{2 (c) Trapezoidal Single cell Box Girder}

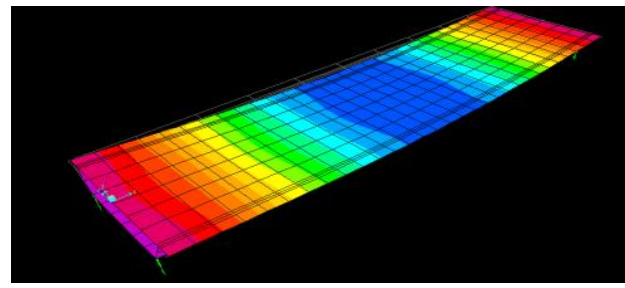

Figure 3.8 First Mode Shape for Trapezoidal Single cell Box Girder 30m Span.

\subsection{2 (d) Trapezoidal Double cell Box Girder}

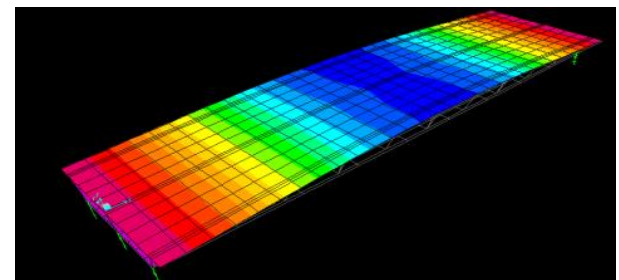

Figure 3.9 First Mode Shape for Trapezoidal Double cell Box Girder 30m Span.

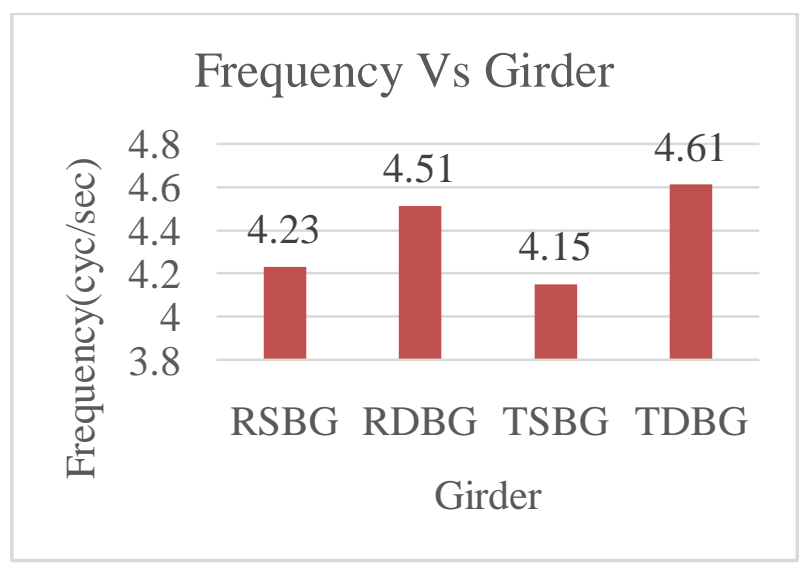

Figure 3.10 Frequency (cyc/sec) Values For different girders shapes for $30 \mathrm{~m}$ Span
From figure 3.10 , it is observed that the maximum frequency is for Rectangular Double cell Box Girder (RDBG) in all considered girders. It is observed that there is an increase in stiffness of $6.6 \%, \%$ for RDBG and TDBG and decrease of $8.9 \%$ for TSBG when compared to RSBG.

Table 3.3.Natural Time Period and Frequencies for Different girders for $40 \mathrm{~m}$ Span

\begin{tabular}{|l|l|l|}
\hline GIRDERS & $\begin{array}{l}\text { Time Period } \\
\text { (sec) }\end{array}$ & $\begin{array}{l}\text { Frequency } \\
\text { (cyc/sec) }\end{array}$ \\
\hline RSBG & 0.35 & 2.84 \\
\hline RDBG & 0.34 & 2.86 \\
\hline TSBG & 0.35 & 2.82 \\
\hline TDBG & 0.35 & 2.83 \\
\hline
\end{tabular}

3.3.3 For $40 m$ Span

\subsection{3 (a) Rectangular Single cell Box Girder}

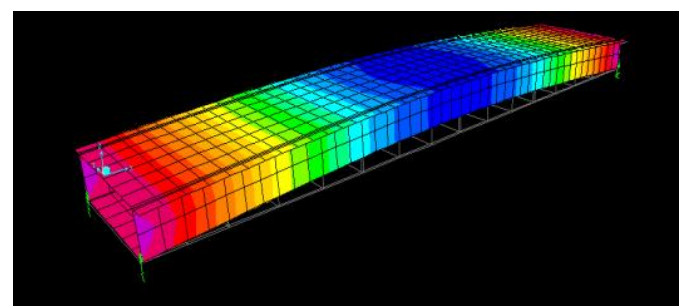

Figure 3.11 First Mode Shape for Rectangular Single cell Box Girder 40m Span.

3.3.3 (b) Rectangular Single cell Box Girder

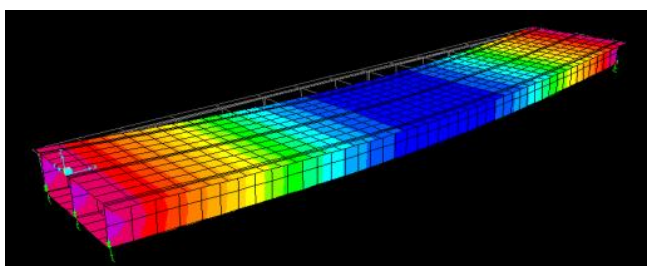

Figure 3.12 First Mode Shape for Rectangular Single cell Box Girder40m Span.

\subsection{3 (c) Trapezoidal Single cell Box Girder}

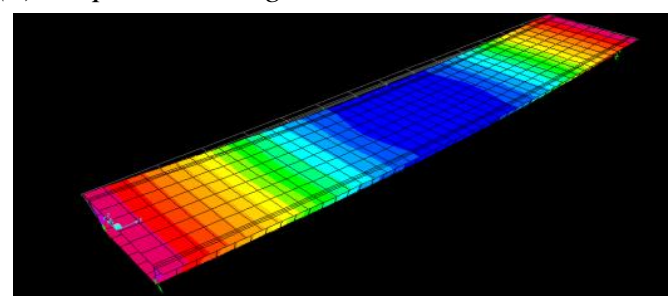

Figure 3.13 First Mode Shape for Trapezoidal Single cell Box Girder 40m Span.

3.3.3 (d) Trapezoidal Double cell Box Girder

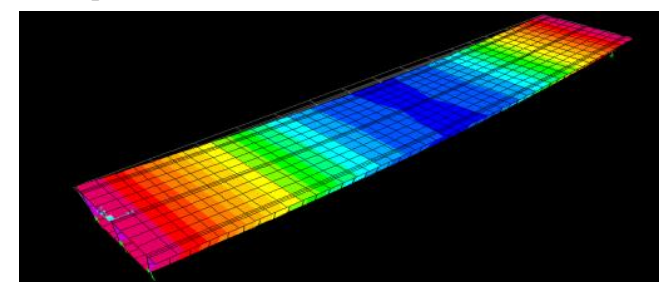

Figure 3.14 First Mode Shape forTrapezoidal Double cell Box Girder 40m Span.

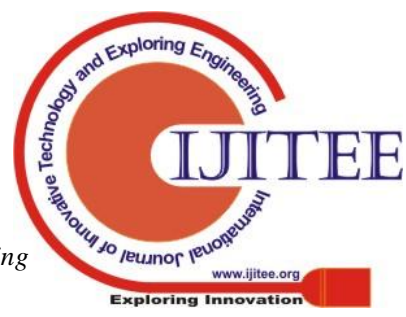




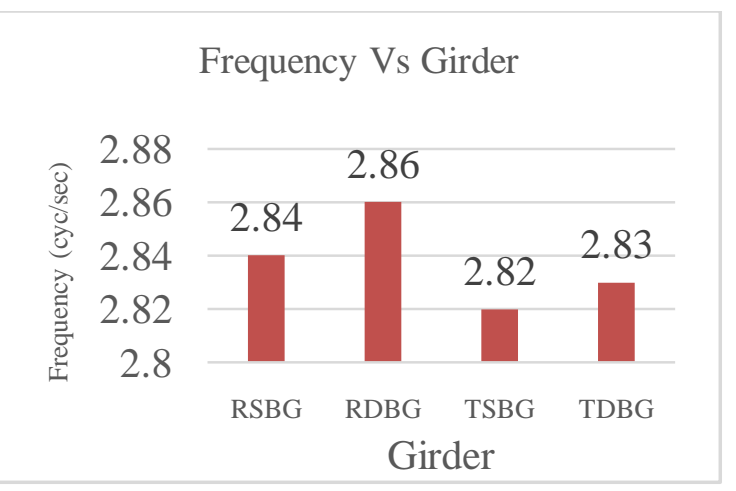

Figure 3.15 Frequency (cyc/sec) Values For different girders shapes for $40 \mathrm{~m}$ Span.

From figure 3.15,it is observed that the maximum frequency is for Rectangular Double cell Box Girder (RDBG) in all considered girders. It is observed that there is an increase in stiffness of $2 \%, 1 \%$ for RDBG and TDBG and decrease of $0.07 \%$ for TSBG when compared to RSBG.

Table 3.4. Natural Time Period and Frequencies for Different girders for $50 \mathrm{~m}$ Span

\begin{tabular}{|l|l|l|}
\hline GIRDERS & $\begin{array}{l}\text { Time } \\
\text { Period }(\mathbf{s e c})\end{array}$ & $\begin{array}{l}\text { Frequency } \\
\text { (cyc/sec) }\end{array}$ \\
\hline RSBG & 0.18 & 5.32 \\
\hline RDBG & 0.17 & 5.73 \\
\hline TSBG & 0.19 & 5.29 \\
\hline TDBG & 0.17 & 5.69 \\
\hline
\end{tabular}

3.3.4 For 50m Span

3.3.4 (a) Rectangular Single cell Box Girder

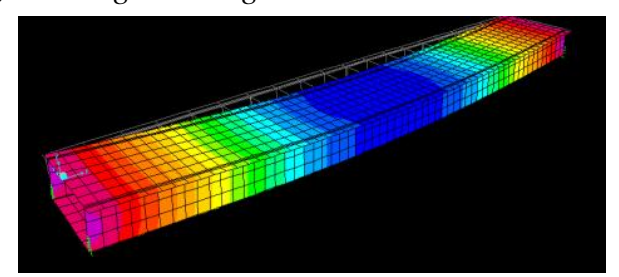

Figure 3.16 First Mode Shape for Rectangular Single cell Box Girder 50m Span.

3.3.4 (b) Rectangular Double cell Box Girder

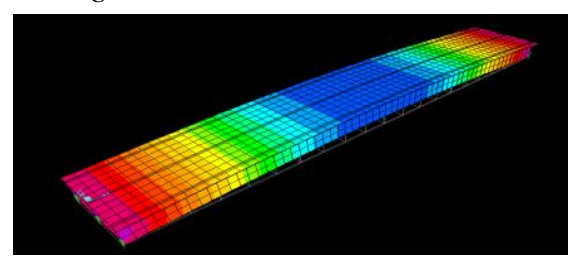

Figure 3.17 First Mode Shape for Rectangular Double cell Box Girder40m Span.

3.3.4 (c) Trapezoidal Single cell Box Girder

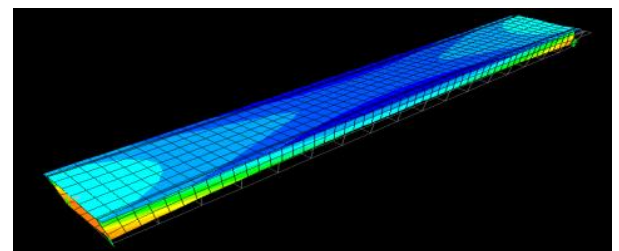

Figure 3.18 First Mode Shape for Trapezoidal Single cell Box Girder 50m Span.

3.3.4 (d)Trapezoidal Double cell Box Girder

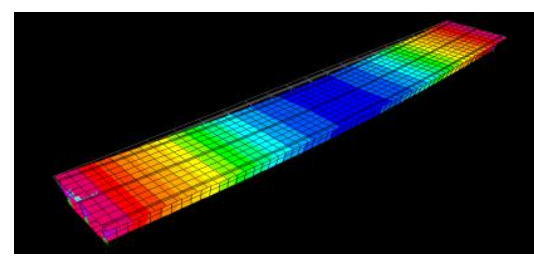

Figure 3.19 First Mode Shape for Trapezoidal Double cell Box Girder 50m Span.

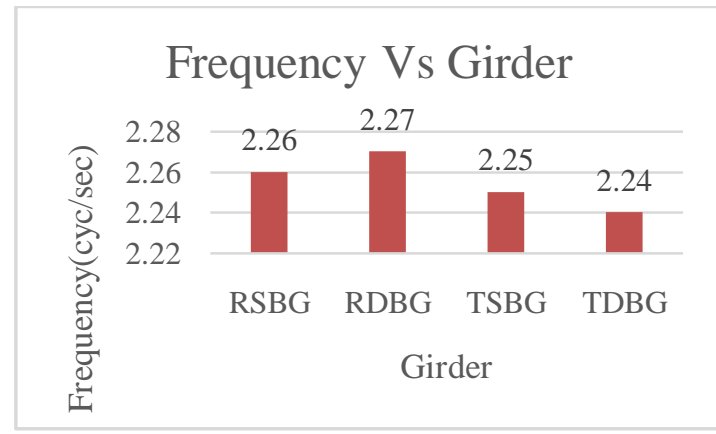

Figure 3.20 Frequency (cyc/sec) Values For different girders shapes for $50 \mathrm{~m}$ Span

From figure 3.20 , it is observed that the maximum frequency is for Rectangular Double cell Box Girder (RDBG) in all considered girders. It is observed that there is an increase in stiffness of $7.7 \%, 6.9 \%$ for RDBG and TDBG and decrease of $0.5 \%$ for TSBG when compared to RSBG.

\subsection{STIFFNESS FOR DIFFERENT GIRDERS}

Below results shows the stiffness values obtained for different types of girders with 4 different spans subjected to Class AA Tracked Vehicle.

$$
f_{\mathrm{n}}=\frac{1}{2 \pi} \sqrt{\frac{k}{m}}
$$

$\mathrm{f}=$ natural frequency $($ cycles/sec)

$\mathrm{m}=$ mass $(\mathrm{kg})$

$\mathrm{k}=$ stiffness $(\mathrm{N} / \mathrm{m})$

Table 3.6.Frequencies (cyc/sec) and Stiffness $(\mathrm{kN} / \mathrm{m})$ for Different girders for 20m Span

\begin{tabular}{|l|l|l|}
\hline GIRDERS & $\begin{array}{l}\text { Frequency } \\
\text { (cyc/sec) }\end{array}$ & $\begin{array}{l}\text { Stiffness } \\
(\mathbf{k N} / \mathbf{m})\end{array}$ \\
\hline RSBG & 5.32 & 122.20 \\
\hline RDBG & 5.73 & 144.74 \\
\hline TSBG & 5.29 & 116.20 \\
\hline TDBG & 5.69 & 137.49 \\
\hline
\end{tabular}

Table 3.7.Frequencies (cyc/sec) and Stiffness ( $\mathrm{kN} / \mathrm{m})$ for Different girders for 30m Span

\begin{tabular}{|l|l|l|}
\hline GIRDERS & $\begin{array}{l}\text { Frequency } \\
\text { (cyc/sec) }\end{array}$ & $\begin{array}{l}\text { Stiffness } \\
\text { (kN/m) }\end{array}$ \\
\hline RSBG & 4.23 & 80.03 \\
\hline RDBG & 4.51 & 94.18 \\
\hline TSBG & 4.35 & 81.49 \\
\hline TDBG & 4.61 & 95.07 \\
\hline
\end{tabular}


Table 3.8.Frequencies (cyc/sec) and Stiffness $(\mathrm{kN} / \mathrm{m})$ for Different girders for $40 \mathrm{~m}$ Span

\begin{tabular}{|l|l|l|}
\hline GIRDERS & $\begin{array}{l}\text { Frequency } \\
\text { (cyc/sec) }\end{array}$ & $\begin{array}{l}\text { Stiffness } \\
(\mathbf{k N} / \mathbf{m})\end{array}$ \\
\hline RSBG & 2.84 & 37.46 \\
\hline RDBG & 2.86 & 39.81 \\
\hline TSBG & 2.82 & 35.70 \\
\hline TDBG & 2.83 & 37.81 \\
\hline
\end{tabular}

Table 3.9. Frequencies (cyc/sec) and Stiffness $(\mathrm{kN} / \mathrm{m})$ for Different girders for 50m Span

\begin{tabular}{|l|l|l|}
\hline GIRDERS & $\begin{array}{l}\text { Frequency } \\
\text { (cyc/sec) }\end{array}$ & $\begin{array}{l}\text { Stiffness } \\
\text { (kN/m) }\end{array}$ \\
\hline RSBG & 2.26 & 24.72 \\
\hline RDBG & 2.23 & 25.58 \\
\hline TSBG & 2.25 & 23.77 \\
\hline TDBG & 2.2 & 24.21 \\
\hline
\end{tabular}

3.5 COMPARISON OF STIFFNESS WITH DIFFEERENT GIRDERS

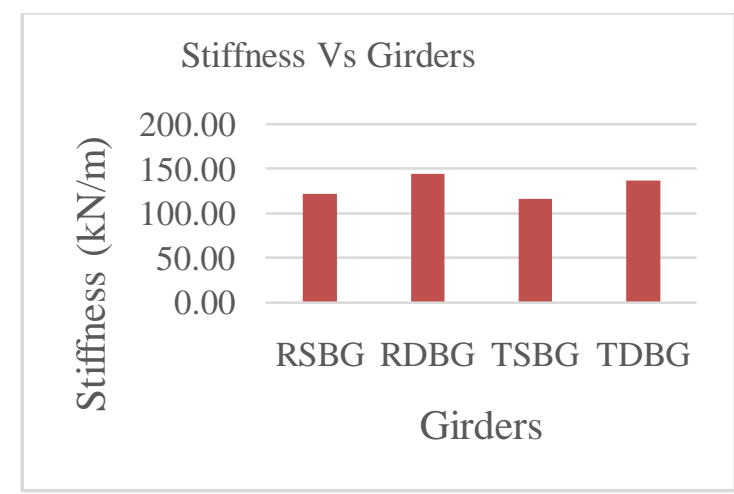

Figure 3.21 Stiffness $(\mathrm{kN} / \mathrm{m})$ Values for different girders shapes for $20 \mathrm{~m}$ Span.

From figure 3.21, it is observed that the maximum stiffness is for Rectangular Double cell Box Girder (RDBG) in all considered girders. It is observed that there is an increase in stiffness of $18.4 \%, 12.5 \%$ for RDBG and TDBG and decrease of $4.9 \%$ for TSBG when compared to RSBG.

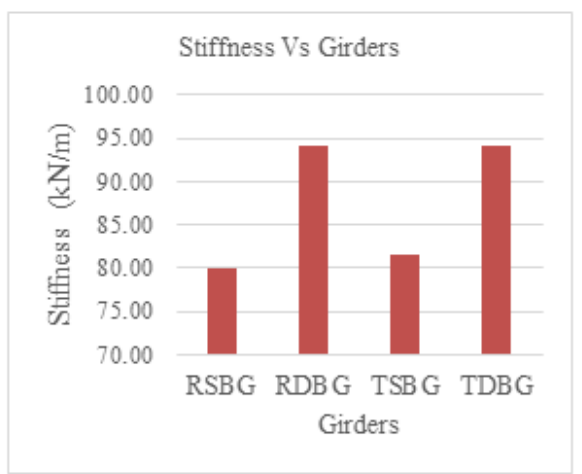

Figure 3.22 Stiffness $(\mathrm{kN} / \mathrm{m})$ Values for different girders shapes for 30m Span.

From figure 3.22, it is observed that the maximum stiffness is for Rectangular Double cell Box Girder (RDBG) in all considered girders. It is observed that there is an increase in stiffness of $17.6 \%, 18.7 \%$ for RDBG and TDBG and decrease of $18.7 \%$ for TSBG when compared to RSBG.

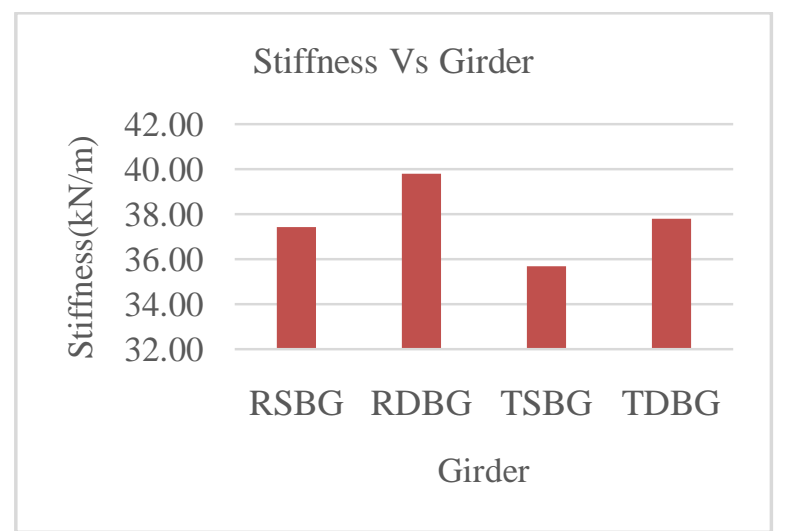

Figure 3.22 Stiffness (kN/m) Values for different girders shapes for 30m Span.

From figure 3.22 , it is observed that the maximum stiffness is for Rectangular Double cell Box Girder (RDBG) in all considered girders. It is observed that there is an increase in stiffness of $17.6 \%, 18.7 \%$ for RDBG and TDBG and decrease of $18.7 \%$ for TSBG when compared to RSBG.

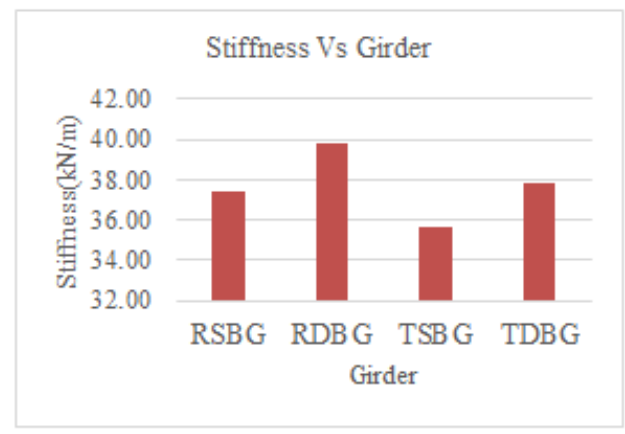

Figure 3.23 Stiffness (kN/m) Values for different girders shapes for $40 \mathrm{~m}$ Span.

From figure 3.23 , it is observed that the maximum stiffness is for Rectangular Double cell Box Girder (RDBG) in all considered girders. It is observed that there is an increase in stiffness of $6.2 \%, 0.9 \%$ for RDBG and TDBG and decrease of $4.6 \%$ for TSBG when compared to RSBG.

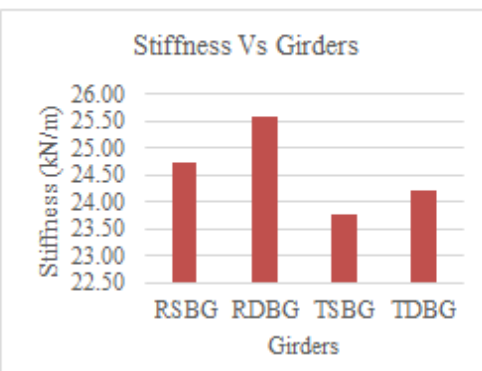

Figure 3.24 Stiffness $(\mathrm{kN} / \mathrm{m})$ Values for different girders shapes for $50 \mathrm{~m}$ Span.

Published By: 
From figure 3.24 , it is observed that the maximum stiffness is for Rectangular Double cell Box Girder (RDBG) in all considered girders. It is observed that there is an increase in stiffness of 3.4\%, 3.3\% for RDBG and TDBG and decrease of $3.8 \%$ for TSBG when compared to RSBG

For all considered spans Rectangular Double cell Box Girder (RDBG) having maximum stiffness when compared to all other considered girders. For all considered spans due to dead and moving load Rectangular Double cell Box Girder (RDBG) having minimum deflection when compared to all other considered girders.

\section{REFERENCES}

1. Abhishek Panda "Analysis and Design of T- Beam Bridge Super Structure Using Limit State Method" International Research Journal of Engineering and Technology (IRJET) eISSN: 2395-0056 Volume: 02 Issue: 07 July-2014.

2. Abrar Ahmed, R.B. Lokhande "Comparitive Analysis and Design of T- Beam and Box Girders.” International Research Journal of Engineering and Technology (IRJET) e-ISSN: 2395-0056 Volume: 04 Issue: 07 July-2017.

3. Anil kumar H, B S Suresh Chandra "Flexural Behavior of Longitudinal Girders of RC T-Beam Deck Slab Bridge". International Journal for Scientific Research \& Development Vol. 3, Issue 05, 2015 ISSN (online): 2321-0613.

4. Anushia K Ajay , Asha U Rao, N.A. PremanandShenoy "Parametric Study of T beam Bridge" International Journal of Civil Engineering and Technology (IJCIET) Volume 8, Issue 6, June 2017.

5. HafsaFarooq, Abdul Arafat Khan "Effect of restrainers on RC Bridge using Linear and Non-linear analysis" IOSR Journal of Mechanical and Civil Engineering (IOSR-JMCE) e-ISSN: 2278-1684,p-ISSN: 2320-334X, Volume 13, Issue

6. Hemalatha A, Ashwin K.N, Dattatreya J.K,S.V.Dinesh "Analysis of RC Bridge Decks for selected National and International Standard Loadings using Finite Element Method”. International Journal of Research in Engineering and Technology eISSN: 2319-1163 pISSN: 2321-7308.

7. KanchanSen Gupta and SomnathKarmakar "Investigations on Simply supported concrete bridge deck slab for IRC vehicle loadings using finite element analysis"Journal of Earth Sciences and Engineering, Volume 04, No 06 SPL, October 2011, PP. 716-719. 